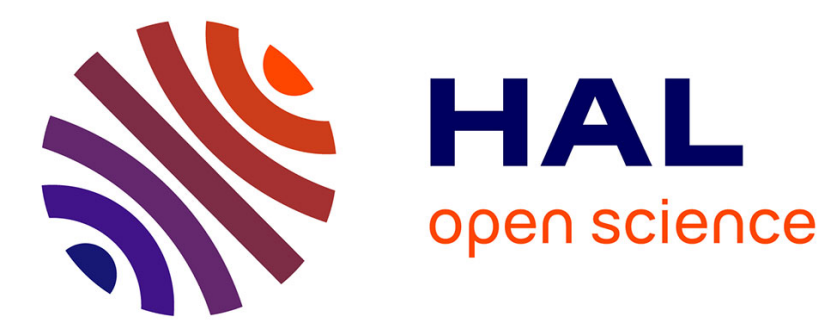

\title{
Space-time approach to commercial property prices valuation
}

\author{
Beatriz Larraz Iribas, Jose Maria Montero Lorenzo
}

\section{To cite this version:}

Beatriz Larraz Iribas, Jose Maria Montero Lorenzo. Space-time approach to commercial property prices valuation. Applied Economics, 2011, pp.1. 10.1080/00036846.2011.581212 . hal-00712371

\section{HAL Id: hal-00712371 \\ https://hal.science/hal-00712371}

Submitted on 27 Jun 2012

HAL is a multi-disciplinary open access archive for the deposit and dissemination of scientific research documents, whether they are published or not. The documents may come from teaching and research institutions in France or abroad, or from public or private research centers.
L'archive ouverte pluridisciplinaire HAL, est destinée au dépôt et à la diffusion de documents scientifiques de niveau recherche, publiés ou non, émanant des établissements d'enseignement et de recherche français ou étrangers, des laboratoires publics ou privés. 


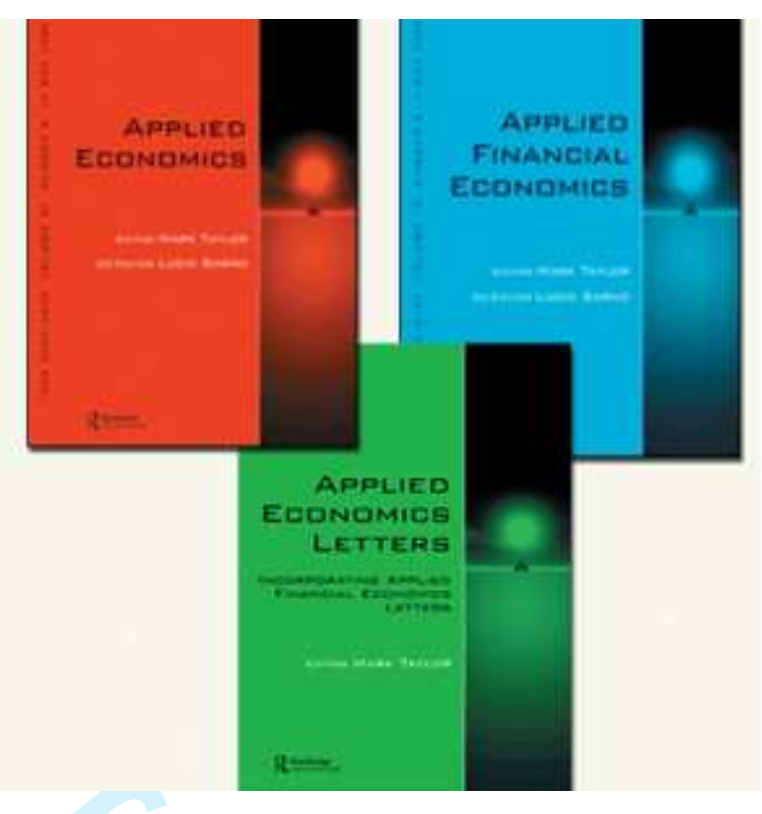

\section{Space-time approach to commercial property prices valuation}

\begin{tabular}{|r|l|}
\hline Journal: & Applied Economics \\
\hline Manuscript ID: & APE-08-0402.R1 \\
\hline Journal Selection: & Applied Economics \\
\hline Date Submitted by the \\
Author: & 28-Sep-2010 \\
\hline Complete List of Authors: & $\begin{array}{l}\text { Larraz Iribas, Beatriz; University of Castilla-La Mancha, Statistics } \\
\text { Montero Lorenzo, Jose; University of Castilla-La Mancha, Statistics }\end{array}$ \\
\hline JEL Code: & $\begin{array}{l}\text { C13 - Estimation < C1 - Econometric and Statistical Methods: } \\
\text { General < C - Mathematical and Quantitative Methods, C10 - } \\
\text { Mathematical and Quantitative Methods, R00 - General < R0 - } \\
\text { General < R - Urban, Rural, and Regional Economics }\end{array}$ \\
\hline Keywords: & $\begin{array}{l}\text { spatial correlation, cokriging, premises prices, house prices, } \\
\text { variogram }\end{array}$ \\
\hline &
\end{tabular}

\section{SCHOLARONE $^{\text {m }}$ Manuscripts}




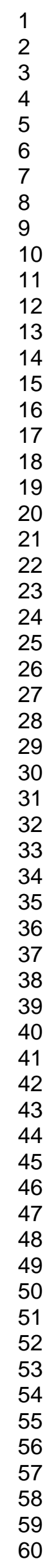

14

15

16

18

19

20

22

23

25

26

27

29

30

32

33

34

35

36

37

38

41

42

4

45

46

47

48

49

51

52

54

55

57

58

59

60

Editorial Office, Dept of Economics, Warwick University, Coventry CV4 7AL, UK 


\title{
Space-time approach to commercial property prices valuation
}

\author{
Montero-Lorenzo, José-María \\ Universidad de Castilla-La Mancha, Toledo, Spain \\ e-mail: jose.mlorenzo@uclm.es \\ Larraz-Iribas, Beatriz \\ Universidad de Castilla-La Mancha, Toledo, Spain \\ e-mail: Beatriz.Larraz@uclm.es
}

\begin{abstract}
:
There exists three ways of approaching real estate prices: the cost approach, the market data approach and the income capitalization approach. In this article, we propose an improvement of the market data approach that takes into account the spatial component. In particular, we propose a modified market data approach based on interpolation, being the structure of the spatial correlation between the prices of properties the main factor to obtain the weights. Interpolation methods have been widely used for estimating real estate prices, but they do not take into account the structure of their spatial dependence. Although this drawback is overcome by kriged estimation, in the case of the prices of commercial properties they do not provide good estimates because the scarceness of the market information. This is why auxiliary information is needed and cokriging methods are used to obtain estimates that are more accurate. The aim of this paper is the comparison of cokriged estimation of premises prices in two different temporal moments in the emblematic old part of Toledo city (Spain), using housing prices as an auxiliary random function due to their strong correlation with the main one. Cokriging, kriging and inverse distance weighting results are compared.
\end{abstract}

KEY WORDS: spatial correlation, cokriging, premises prices, house prices, variogram.

Adress for correspondence:

Beatriz Larraz Iribas

Facultad de Ciencias Jurídicas y Sociales.

Cobertizo de San Pedro Mártir s/n

45071 Toledo

Spain

e-mail: Beatriz.Larraz@uclm.es 


\section{1. - Introduction.}

Valuation of residential properties has been traditionally based only on a comparison with real estate properties recently sold or listed for sale and on knowledge of neighbourhood trends. In developed countries, a property assessor still needs to physically visit the property. Nevertheless, in the last two decades, several studies in the statistical and real estate literature have recommended improvements to the real estate valuation procedures. Each study has improved upon the estimation capacity of earlier ones, either increasing the number of housing characteristics considered or developing new valuation methods. In this sense, most of the articles were based upon hedonic models, which began with Rosen (1974). Malpezzi (2002) made a selective revision of the hedonic models applied to real estate valuation, and Goodman and Thibodeau (2003) developed an interesting application in Dallas County (USA). Similarly, Stevenson (2004) applied hedonic pricing models in Boston (USA) and Ellen et al. (2007) use hedonic regression models in New York (USA) that explain the sale price of a property.

Approximately twenty years ago, artificial intelligence was designed to replicate the human brain's learning process. Neural networks have been applied to real estate valuation processes. Notable studies include Worzala et al. (1995) in Colorado (USA), Limsombunchai et al. (2004) in New Zealand and Caridad et al. (2008) in Córdoba (Spain). Additionally, spatial econometric approaches have been used to estimate housing prices; e.g., 
Brasington and Hite (2005) developed spatial hedonic regressions in six North American cities and Anselin and Lozano-Gracia (2008) applies similar methods to Southern California (USA). The analytic network process has also been applied, though infrequently, to property valuation, and this approach combines quantitative and qualitative attributes (Aznar et al., 2010). Brint (2009) predicted a house's selling price through inflating its previous selling prices using the information provided by repeat sales. Finally, in a geostatistics framework, kriging methods, which takes into account the spatial dependence that real estate prices present, have been applied to punctual property price estimation, as first used by Chica-Olmo (1995, 2007) in Granada (Spain) and Gamez et al. (2000) in Albacete (Spain) and also used more recently, e.g., Montero and Larraz (2006) in Toledo (Spain).

In the scientific literature related to the estimation of real estate prices, almost all the references deal with the price of houses ${ }^{1}$ this fact being perfectly understandable as houses are goods of the highest priority. Dubin (1998), Basu and Thibodeau (1998), Gámez et al. (2000); Din et al. (2001), Clapp et al. (2002), Fik el al. (2003), Case et al. (2004), Han (2004), Militino et al. (2004), Gelfand et al. (2004), Montero and Larraz (2006) and Tsai, Chen and Ma (2008), among others, make some interesting recent contributions from several points of view. Scientific literature about the 
estimation of the price of offices and premises, however, is certainly scarce (Montero, Larraz and Páez, 2009). In the case of the estimation of commercial property prices, the scarceness of scientific papers on the topic is surprising as commercial equipment has undoubted importance in the economic development of urban areas (Scott and Judge, 2000).

Valuation of premises in any place of a particular area is not an easy task because the available information regarding the price of premises (not as comprehensive as that of the price of houses) is usually not enough to provide good estimates. Perhaps this fact, apart from the different market sizes, might explain why in most of countries property valuation agencies, associations of notaries and registrars of deeds, researchers, etc., devote their efforts essentially towards the housing market and not towards the premises market. Furthermore, because prices of the properties are spatially correlated, methods that are able to incorporate the role of space into conventional estimates are needed. These two facts - little available information and spatial correlation - have been the starting point to use cokriging as a methodology for the estimation of premises prices when sample sizes are small, following Montero, Larraz and Paez (2009) and Montero and Larraz (2010).

\footnotetext{
${ }^{1}$ We use the term 'house prices' throughout, in accordance with the quoted literature, even though the data only include flatted properties.
} 
Under this framework, the main aim of this paper is the comparison of the valuation of commercial property prices in two temporal moments, using a non-spatial classic interpolation method (inverse distance weighting (IDW), a univariate (kriging) and a multivariate (cokriging) spatial valuation method. This paper not only faces the difficult task of estimating premises prices but also do it by importing the most recent methods from geostatistics, showing the comparison of the results for the period 20072009.

Having said that, the outline of the remaining part of this paper is the following: In Section 2, cokriging methodology is briefly described. Section 3 shows the commercial properties valuation procedure that has been carried out in the emblematic old part of Toledo city (Spain), which is included on the UNESCO's World Heritage List. This third section firstly describes the database and shows how to obtain equivalent classes of premises and houses. Subsequently, we proceed to model the structure of the spatial dependence of premises and house prices, as well as to generate and map the premises prices estimations. Finally, ordinary cokriging (OCK), kriging (OK) and inverse distance weighting (IDW) estimates are compared in two different temporal moments in order to appreciate the importance of include the spatial information and the use of an auxiliary random function (house prices), correlated with the main one (premises prices), to improve the 
accuracy of the univariate estimates. The paper ends with some concluding remarks.

\section{2. - Statistical Methodology}

As it is well known, trying to estimate the price of a property is not an easy task, neither from a model driven approach nor from a data driven approach. According to the market data approach, it can be estimated from a set of valuated comparable, competitive properties located close to it. Now, the problem is how to estimate the price of a property (house, premises, office, etc.) from these known valuated properties. Due to the fact that real estate prices are spatially correlated, their estimation should be carried out by using spatial estimation techniques that take into account the existence of such spatial correlation, and in particular, by using kriging and cokriging methodology. Statistically speaking, kriging, the univariate approach to this problem, considers only the random function of interest (in our case the premises prices) and cokriging, the multivariate approach, takes into account other random functions correlated with the main one (house prices, offices prices, etc.). When estimating premises prices, the available information about the prices of comparable, competitive premises, uses to be certainly scarce and this is the reason why cokriging is preferable to kriging. 
Following Montero, Larraz and Paez (2009), consider $\mathbf{X}=\left(X_{1}, X_{2}, \ldots, X_{m}\right)^{t}$, a vector of intrinsic random functions: price of premises, prices of houses,..., price of offices. In this case, cokriging is called ordinary cokriging (OCK). Consider the partial heterotopy case, that is, the locations where the premises prices are known are partially the same ones where we know the house prices, offices prices, etc. This is the real case in the real estate markets. To estimate the price of a premises in a particular location, $X_{i}\left(\mathbf{s}_{0}\right)$, from the prices of premises, houses, offices, etc., corresponding to the valuation set (the sample) cokriging propose a weighted linear combination of the data values from $X_{j}(j=1, \ldots, m)$ located at sampled points in the neighborhood of $\mathbf{s}_{0}$ :

$$
X_{i}^{*}\left(\mathbf{s}_{0}\right)=\sum_{j=1}^{m} \sum_{\alpha=1}^{n_{j}} \lambda_{\alpha}^{j} X_{j}\left(\mathbf{s}_{\alpha}^{j}\right)
$$

with $\left\{\mathbf{s}_{\alpha}^{j}, \alpha=1, \ldots, n_{j}\right\}$ being the set of locations where $X_{j}, j=1, \ldots, m$, have been sampled and $n_{1}, n_{2}, \ldots, n_{m}$ the sizes of the sample sets. The weights $\lambda_{\alpha}^{j}, \alpha=1, \ldots, n_{j}, j=1, \ldots, m$, are calculated to ensure that the estimator is optimal, in the sense that it is unbiased and with minimum error-variance by solving the following OCK system:

$$
\left\{\begin{array}{l}
\sum_{k=1}^{m} \sum_{\beta=1}^{n_{k}} \lambda_{\beta}^{k} \gamma_{j k}\left(\mathbf{s}_{\alpha}^{j}-\mathbf{s}_{\beta}^{k}\right)+\omega_{j}=\gamma_{j i}\left(\mathbf{s}_{\alpha}^{j}-\mathbf{s}_{0}\right) \forall j=1, \ldots, m ; \forall \alpha=1, \ldots, n_{j} \\
\sum_{\alpha=1}^{n_{j}} \lambda_{\alpha}^{j}=\delta_{i j}=\left\{\begin{array}{lll}
1 & \text { si } & i=j \\
0 & \text { si } & i \neq j
\end{array}\right.
\end{array}\right.
$$


The direct and cross variograms, which are represented by $\gamma_{j k}\left(\mathbf{s}_{\alpha}^{j}-\mathbf{s}_{\beta}^{k}\right)$ $\forall j, k=1, \ldots, m ; \forall \alpha=1, \ldots, n_{j} ; \forall \beta=1, \ldots, n_{k}$, are used to show the structure of the spatial dependencies.

On the other hand, if the same task of estimating premises prices is approached from a univariate point of view, ordinary kriging $(\mathrm{OK})$ is the particular case of OCK when interpolation is only based on one random function (the main one, in our case the price of premises). In other words, OCK reduces to OK when all OCK weights are zero except for the variable of interest (see Montero and Larraz, 2006).

Finally, IDW-based methods are interpolation methods with a weighting mechanism assigning more influence to the data points near the location where the estimation in being carried out (see Johnston et al. 2001). In this article power two $(p=2)$ of the inverse of the Euclidean distances has been considered.

\section{3. - Estimating premises prices in the Historic City of Toledo.}

This section shows the comparative results obtained from the application of this multivariate spatial estimation procedure to the premises prices in the old part of Toledo city (Spain), taking the price of houses in that area as an auxiliary process. 
There are several reasons for having chosen this emblematic area: (i) It is a World Heritage City, (ii) it is an excellent area for exploring the commercial real estate market due to its tourist character and (iii) it has neither geographical accidents nor artificial barriers inside the walls that could break down the spatial dependence structure. The study area and its position in Spain are depicted in Figure 1.

\section{INSERT FIGURE 1}

\section{1.- Database}

The database contains information about premises and houses sited in the historical part of Toledo city. The data correspond to 123 commercial properties and 223 houses for sale in the third quarter of 2007, being the sample size of 106 and 203 premises and houses, respectively, in the third quarter of 2009. The information has been provided by the real estate agencies $^{2}$ that operate in this historical area and it refers to the market price, age, location, condition and surface. Additionally, it is known whether the premises have a basement or not, and, in the case of houses, whether they

\footnotetext{
${ }^{2}$ We are extremely grateful to Imagil Gestión Inmobiliaria, Zocopiso, Amian Inmobiliaria, Imperial Inmabel S.L., Agencia Inmobiliaria Gudiel, Inmobiliaria Castaño, Agrufinca, Acrópolis, Albatros, Teleinmobiliaria, Inmobiliaria Época, Inmobiliara Ábaco, Simar, Agencia Inmobibliaria Orgaz and Fondo Piso Toledo for their first-rate help in providing the detailed data to the Department of Statistics at the University of Castilla-La Mancha (Spain).
} 
have parking space or not. Obviously, the age of a property usually has an important influence on its price, but in a historical part of a city like Toledo the influence of this factor vanishes. This is the reason why it has not been considered in the analysis. Moreover, we have detected some deficiencies in the measurement of the surface, having decided to consider it as a categorical variable ${ }^{3}$. Obviously, there also exist more explanatory variables but unfortunately they are not provided by the real estate agencies for research purposes.

\section{2. - Obtaining equivalent classes of houses and premises ${ }^{4}$.}

In the original database, the prices are unadjusted for housing and premises mix. So, we do not know at this point if the higher prices in some areas reflect higher property values per square meter or if the houses or premises in those areas possess some features that make them more expensive.

In order to isolate the spatial component of premises and house prices we have proceeded to adjust for housing and premises mix as follows (for more details, see Goodman (1978) and Cheshire and Sheppard (1995), among others): Tests have been made as to whether all the levels of every characteristic of premises and houses we have information about (see Tables 1 and 2), have the same effect on the price. In the event that this hypothesis

\footnotetext{
${ }^{3}$ It does not significantly affect results.

${ }^{4}$ The analysis has been conducted in terms of price per square meter.
} 
is rejected, the significant differences have been estimated and removed from prices. Once these differences are removed, houses and premises are equivalent ${ }^{5}$ with regard to the features considered (in this sense we have an "equivalent class" of houses and another one of premises) and the variability of the "new" prices is attributable to the spatial location of the properties. Specifically, factors and levels considered have been the following:

\section{INSERT TABLE 1}

\section{INSERT TABLE 2}

In essence, this procedure to obtain equivalent classes of premises and houses - comparable, competitive premises or houses-, based on the analysis of variance (ANOVA), is equivalent to the traditional hedonic model. In fact, the hedonic model is a reparametrization of the ANOVA structure but we have preferred the last one because it allows for both, multiplicative and additive factors. So, the ANOVA procedure we propose to obtain equivalent classes can be seen as a two-steps hedonic model. From now on, the premises and house prices we work with are the equivalent ones.

\footnotetext{
${ }^{5}$ Adjusted for housing and premises mix, in Fotheringham et al. (2002) terminology, although these authors also
} 


\section{3. - Spatial dependence and variogram modeling.}

As pointed out in the introduction, from our point of view, the problem of estimating premises prices in the context of a market data approach can only be adequately analyzed by taking into account the relative locations of the observations because spatial correlation is a typical characteristic of the price of properties. So, after having constructed both the databases of equivalent prices for houses and premises, we firstly have computed the well-known Moran's I statistic (also known as Moran's contiguity ratio) for identifying a global pattern of spatial correlation (for an analysis of its properties and its null distribution see, for example, Cliff and Ord, 1981; Anselin, 1988 and Tiefelsdorf and Boots, 1995).

In concrete, we have tested randomness versus positive correlation using a contiguity matrix whose elements are the inverses of the distances among locations. Table 3 reports the sample values of the I-statistic obtained for premises prices and house prices in each temporal moment. In every case the standardized values of the $I$-statistic lead to the rejection, at the $5 \%$ level of significance, of randomness in favor of the alternative of positive spatial autocorrelation.

INSERT TABLE 3

use the expression "equivalent houses". 
Having detected, as expected, positive spatial autocorrelation in both, premises and houses prices data sets in both temporal moments, we have next proceeded to represent that spatial dependence in both cases by the appropriate theoretical variogram model, and to account for crossdependence between both processes -since cokriging methods are used to estimate the prices of premises- we have also selected the suitable cross variogram.

Cross and direct variograms are usually obtained in two steps. First, point estimates of the variograms are obtained using the classical variogram estimator based on the method-of-moments (it is supposed constant-mean, see Lark and Papritz, 2003). The second step is to fit a theoretical variogram function to the sequence of average dissimilarities, according to the linear model of corregionalization (see, for example, Journel and Huijbregts, 1978, p. 171-175; Goovaerts, 1997, p. 108-115 and Wackernagel, 2003, p. 175 and 176) because it is the usual strategy to ensure a positive definite model. The experimental cross and direct variograms appear in Figure 2 with their respective fitted models. The values of the parameters are reported in Table 4.

\author{
INSERT FIGURE 2 \\ INSERT TABLE 4
}

Editorial Office, Dept of Economics, Warwick University, Coventry CV4 7AL, Ủ 
Cokriging results are dependent on the autocorrelation model of the principal and auxiliary random functions, as well as on the cross-correlation model; hence, the variogram modeling process and the need for high-quality models are of paramount importance. The validation procedure may be carried out rigorously by having a separate set of sample data against which to compare cokriged estimates, but in our study case (as in most cases) this means a waste of information, and validation has been done by crossvalidation. or "leave-one-out" procedure (see, for example, Sinclair and Blackwell, 2002, p. 221). Specifically, models from Table 4 provide at Q3 2007, 119 robust estimates when estimating premises prices $(96.7 \%$ from a total of 123) and 214 in the case of the house prices $(96.0 \%$ from a total of 223), and at Q3 2009, 103 robust estimates when estimating premises prices (97.2\% from a total of 106) and 195 in the case of the house prices (95.6\% from a total of 203), an estimate being robust when its standardized value belongs to the interval $[-2.5 ; 2.5]$. These percentages of robust estimates (greater than 95\%) lead us to consider models from Table 4 and Figure 3 valid for cokriging estimation.

\section{4.- Results.}

Once we have decided the combination of theoretical variograms that best captures the structure of the spatial dependence in the area under study, we can proceed to estimate the premises prices at Q3 2007 and Q3 2009 by 
using the cokriging methodology. In particular, as the fitted variograms stabilize around the variance of the data, the random functions relative to the price of premises and houses can be considered second-order stationary and OCK is used to map the estimates.

We have also estimated the price of premises by OK and by the IDW method. The aim is to compare the three procedures (a classic interpolation method versus two spatial ones) and check, as expected from the theoretical literature on geostatistics, that OCK is more accurate than OK.

To perform the OCK estimation we have initially designed a polygon representing the outline of the study area, the holes corresponding to the places occupied by cultural buildings, such as the Cathedral, the Alcazar, Christian churches, Islamic monuments, Synagogues, etc. Subsequently, we have drawn a regular grid of 3.30 meter mesh over the above mentioned polygon, having performed the estimation in the nodes of the grid. As the neighborhood was a moving one with a radius of 132 meters, 68911 estimations were carried out in both temporal moments (Q3 2007 and Q3 2009).

Finally, these 68911 estimates are depicted in the OCK estimation map (Figure 3, where the price per square meter is considered as an $\mathrm{XY}$ projection). The basic descriptive statistics of these OCK estimates are reported in Table 5. On average, the commercial property valuations have 
decreased a 7.5\% from Q3 2007 to Q3 2009, while the minimum price is a $12.1 \%$ bigger in 2007 than in 2009 and the maximum a $4.2 \%$ smaller. The variation within the values, measured through the variation coefficient, has decreased a $20.3 \%$ in the period considered.

\section{INSERT FIGURE 3}

\section{INSERT TABLE 5}

As it can be appreciated from the estimation maps of both years (Figure 3), the areas where premises prices are cheap (darkest zones) are easily distinguished from the areas where they are more expensive (lightest zones). The results of Q3 2007 are in tune with the Q3 2009 ones. In particular, the OCK estimation maps reveals that the highest prices per square meter appear, as expected, in the tourist zone: (i) the north-east part of the study area, corresponding to the emblematic Zocodover Square, the Cathedral surroundings and the streets that connect both zones, and (ii) the Sefardi district, in the south-west of the polygon. In both areas prices exceed $3000 \mathrm{f} / \mathrm{m}^{2}$. There are another two areas with prices between 2500 and $3000 \mathrm{f} / \mathrm{m}^{2}$, corresponding to the place near where tourist buses leave visitors: the escalator to the old city (in the north-west) and the old city's main entry point (Bisagra Gate, in the south-west). In the north, prices range from 1500 
to $2500 \mathrm{f} / \mathrm{m}^{2}$, while, finally, in the south-east area (the darkest one) prices are lower than $1000 \mathrm{f} / \mathrm{m}^{2}$.

\section{INSERT FIGURE 4}

Figure 4 shows the standard deviation maps corresponding to the 2007 and 2009 valuations: The darker the colour, the lower the standard deviation. 123 and 106 points in black, in each year respectively, can be clearly appreciated, that is, with null standard deviation; obviously they correspond to the sampled locations, as OCK is an exact multivariate interpolator. From Figure 5 it can be concluded that, as it happened in the estimation map, the standard deviation results of Q3 2007 are in tune with the Q3 2009 ones. Note that in the areas most sampled, the variability of the estimation error, in standard deviation terms, ranges between 100 and 200 $€ / \mathrm{m}^{2}$, while in zones with few sampled locations the standard deviation increases to $300-350 € / \mathrm{m}^{2}$. It can also be appreciated that the greater the distance between the estimated points to the sampled locations, the more the standard deviation increases; this fact implies that the accuracy of the estimates decreases dramatically in locations separated from the sample site.

The ordinary cokriging procedure carried out provides estimates in all and each location of the area under study. These prices would correspond 
to an equivalent set of premises, and real estimates would be easily computed by incorporating the factor effects relative to each premises. Figures 2 to 4 have been obtained by using ISATIS, a spatial statistical program jointly developed by Geovariances ${ }^{6}$ and L'Ecole des Mines de Paris.

\section{5. - Cokriging versus Kriging and Inverse Distance Weigthing.}

Once the OCK estimation and surface maps have been obtained, we next proceed to compare the results obtained by OCK multivariate methodology and the OK univariate procedure with the ones obtained through a classical interpolation method (IDW). OK estimates have been computed incorporating in the weighting mechanism the premises prices direct variogram reported in Table 4 and IDW procedure has considered power 2. The comparison criterion is the interpolation accuracy when carrying out a cross validation procedure. In particular, cokriging versus kriging estimation variances are compared. The comparison results are reported in Table 6.

\section{INSERT TABLE 6}

From Table 6 it can be concluded that using a classic non spatial interpolation method (IDW) the valuations has a downwards bias on average being the variation within the errors bigger than using the spatial

\footnotetext{
${ }^{6}$ See http://www.geovariances.fr.
} 
methods. When comparing OK versus OCK results, as expected (the correlation coefficients between premises and house prices, computed with the 65 and 58 pairs of prices, respectively in 2007 and 2009, corresponding to locations where were known both the price of a premises and the price of a house, are $\rho_{Q 3-2007}=0.696$ and $\left.\rho_{Q 3-2009}=0.665\right)$, OCK procedure has several advantages. On the one hand, regarding the year 2007, (i) the mean estimation error decreases by $10.2 \%$ (from -1.672 to 1.501 ) the $\mathrm{OK}$ result and by $91.7 \%$ (from -18.240 to 1.501 ) the IDW ones, (ii) the mean error, in standardized terms, decreases by $70 \%$ (from -0.015 to 0.0045 ), (iii) the variance of the estimation errors decreases by $11.58 \%$ (from 91186.233 to 80621.447) the variance of the OK ones and by $17.5 \%$ (from 97779.020 to 80621.447) the variance of the IDW results; and finally, (iv) the reduction in variance increases to $15.95 \%$ (from 1.097 to 0.922 ) when standardized errors are considered.

On the other hand, in connection with the year 2009 results, (i) the mean estimation error decreases by $13.08 \%$ (from -1.850 to 1.608 ) the OK result and by $92.10 \%$ (from -20.347 to 1.608 ) the IDW ones, (ii) the mean error, in standardized terms, decreases by $59.26 \%$ (from -0.054 to 0.022 ), (iii) the variance of the estimation errors decreases by $8.83 \%$ (from 95438.844 to 87007.087 ) the variance of the OK ones and by $12,40 \%$ (from 999320.372 to 87007.087) the variance of the IDW results; and finally, (iv) the reduction in variance increases to $9.74 \%$ (from 1.129 to 1.019 ) when 
standardized errors are considered. When comparing the first period results with the second period ones, the situation has worsened slightly due to the sample size (smaller in 2009 case), showing the final values also improvements in OCK cases.

\section{4. - Conclusions}

In this paper, we have shown the importance of considering the structure of the spatial dependence among the prices of properties when estimating them. Furthermore, the existing correlation between the prices of different types of properties (in our case, houses and premises) has been used to obtain more accurate estimates of premises prices, as available information about premises prices is usually less than about house prices. In this sense, cokriging methodology constitutes a great advance in the market data approach to estimate the value of a piece of real estate, in general, and of a commercial property, in particular.

Before obtaining any estimates, we have proceeded to study the spatial structure. It comprises two steps: (i) adjusting for housing and premises mix in order to isolate the spatial component of premises and house prices; (ii) modelling the direct and cross variograms according to the linear model of corregionalization to ensure a positive definite model. Next, we have evaluated the IDW classical interpolation method, the univariate 
$\mathrm{OK}$ and the multivariate OCK as to their ability to estimate the premises prices in the historical area of Toledo city (Spain). In particular, we have considered the spatial structure of property prices to enhance the IDW results and the OCK methodology to improve OK estimates by adding an auxiliary random function corresponding to the house prices in the study area.

As expected, and in accordance with specialized literature on geostatistics, our results have shown that spatial methods are more accurate than IDW and that OCK has a clear advantage over OK. The results indicate that the use of an auxiliary random function improves OK estimates, which is crucial when the extent of the information on the main one is not as much as desirable. This is precisely the case when estimating premises prices as information on them is usually scarce.

Acknowledgements: This research has been supported by the Spanish MICINN through the project CSO2009-11246.

\section{References}

Anselin, L. (1988) Spatial Econometrics: Methods and Models. Boston, Kluwer Academic Press.

Anselin, L and Lozano-Gracia, N. (2008) Errors in variables and spatial effects in hedonic house price models of ambient air quality, Empirical Economics, 34, 5-34. 
Aznar, J., Ferrís-Oñate, J. and Guijarro, F. (2010) An ANP framenwork for property pricing combining quantitative and qualitative attributes, Journal of the Operational Research Society, 61, 740-755.

Basu, S. and Thibodeau, T.G. (1998) Analysis of Spatial Correlation in House Prices, Journal of Real Estate Finance and Economics, 17 (1), $61-85$.

Brasington, D.M. and Hite, D. (2005) Demand for environmental quality: a spatial hedonic analysis. Regional Science and Urban Economics, 35, $57-82$.

Brint, A. (2009) Predicting a house's selling price through inflating its previous selling price, Journal of Operational Research Society, 60, $339-347$.

Caridad, J.M., Núñez, J. and Ceular, N. (2008) Metodología de precios hedónicos vs. Redes Neuronales Artificiales como alternativas a la valoración de inmuebles. Un caso real. Revista CT/Catastro, 62, 27-42.

Case, B., Clapp, J.M., Dubin, R.A. and Rogriguez, M. (2004) Modeling spatial and temporal house price patterns: A comparison of four models, Journal of Real Estate Finance and Economics, 29 (2), 167-191.

Cheshire, P. and Sheppard, S.C. (1995) On the Price of Land and the Value of Amenities, Economica, 62 (246), 247-267.

Chica-Olmo, J. (1995) Spatial Estimation of Housing Prices and Locational Rents. Urban Studies, 32, 1331-44. 
Chica-Olmo, J. (2007) Prediction of Housing Location Price by a Multivariate Spatial Method: Cokriging, Journal of Real Estate Research, 29, 91-114.

Clapp, J.M., Kim, H.-J. and Gelfand, A.E. (2002) Predicting spatial patterns of house prices using LPR and bayesian smoothing, Real Estate Economics, 30 (4), 505-532.

Cliff, A.D. and Ord, J.K. (1981) Spatial Processes: Models and Applications, London: Pion Ltd.

Din, A., Hoesli, M. and Bender, A. (2001) Environmental Variables and Real Estate Prices, Urban Studies, 38 (11), 1989-2000.

Dubin, R.A. (1998) Predicting House Prices using Multiple Listing Data, Journal of Real Estate Finance and Economics, 17 (1), 144-164.

Ellen, I.G., Schwartz, A.E., Voicu, I. and Schill, M.H. (2007) Does federally subsidized rental housing depress neighborhood property values? Journal of Policy Analysis and Management, 26 (2), 257-280.

Fik, T.J., Ling, D.C. and Mulligan, G.F. (2003) Modeling Spatial Variation in Housing Prices: A Variable Interaction Approach, Real Estate Economics, 31 (4), 623-646.

Fleming, M. C. and Nellis, J. G. (1992) Development of standardized indices for measuring house price inflation incorporating physical and locational characteristics, Applied Economics, 24 (9), 1067-1085. 
Florkowski, W.J. and Sarmiento, C. (2005) The examination of pecan price differences using spatial correlation estimation, Applied Economics, 37 (3), 271-278.

Fotheringham, A.S., Brunsdon, C. and Charlton, M. (2002) Geographically Weighted Regression. The Analysis of Spatially Varying Relationships. Chichester: John Wiley \& Sons, LTD.

Gámez, M., Montero, J.M. and García, N. (2000) Kriging Methodology for Regional Economic Analysis: Estimating the housing price in Albacete, International Advances in Economic Research, 6 (3), 438-451.

Gelfand, A.E., Ecker, M.J., Knight, J.R. and Sirmans, C.F. (2004) The Dynamics of Location in Home Price, Journal of Real Estate Finance and Economics, 29 (2), 149-166.

Goodman, A.C. (1978) Hedonic Prices, Price Indices and Housing Markets, Journal of Housing Research, 3, 25-42.

Goodman, A.C. and Thibodeau, G.T. (2003) Housing market segmentation and hedonic prediction accuracy, Journal of Housing Economics, 12, 181-201.

Goovaerts, P. (1997) Geostatistics for natural resources evaluation. NewYork: Oxford University Press.

Han, S.S. (2004) Spatial structure of residential property-value distribution in Beijing and Jakarta, Environment and Planning A, 36 (7), 1259-1283. 
Johnston, K., Ver Hoef, J.M., Krivoruchko, K. and Lucas, N. (2001) Using ArcGIS geostatistical analyst. ESRI Press.

Journel, A.G. and Huijbregts, C.J. (1978) Mining Geostatistics. London: Academic Press.

Lark, R.M. and Papritz, A. (2003) Fitting a linear model of corregionalization for soil properties using simulate annealing, Geoderma, 115, 245-260.

Limsonbunchai, V., Gan, C. and Lee, M. (2004) House price prediction: hedonic price model vs. artificial neural network. American Journal of Applied Sciences, 1 (3), 193-201.

Malpezzi, S. (2002) Hedonic Pricing Models: A Selective and Applied Review, Housing Economics: Essays in Honor of Duncan Maclennan. Edyted by Kenneth Gibb and Anthony O’Sullivan.

Militino, A.F., Ugarte, M.D. and García-Rinaldos, L. (2004) Alternative Models for Describing Spatial Dependence Among Dwelling Prices, Journal of Real Estate Finance and Economics, 29 (2), 193-209.

Montero, J.M. and Larraz, B. (2006) Estimación espacial del precio de la vivienda mediante métodos de krigeado, Revista Estadística Española, 48 (162), 62-108.

Montero, J.M. and Larraz, B. (2010) Interpolation methods for geographical data: Housing and commercial establishment markets, Journal of Real Estate Research, forthcoming. 
Montero, J.M., Larraz, B. and Paez, A. (2009) Estimating Commercial Property Prices: An Application of Cokriging with Housing Prices as Anciliary Information. Journal of Geographical Systems, 11, 407-425.

Rosen, S. (1974) Hedonic Prices and Implicit Markets. Product Differenciation in Pure Competition, Journal of Political Economy 82, 34-55.

Scott, P. and Judge, G. (2000) Cycles and steps in British commercial property values, Applied Economics, 32 (10), 1287-1297.

Sinclair, A.J. and Blackwell, G.H. (2002) Applied Mineral Inventory Estimation. Cambridge University Press, Cambridge

Stevenson, S. (2004) New empirical evidence on heteroscedasticity in hedonic housing models, Journal of Housing Economics, 13 (2), 136153.

Tsai, I-C., Chen, M-C and Ma, T. (2010) Modelling house price volatility states in the UK by switching ARCH models, Applied Economics, 42 (9), 1145-1153.

Tiefelsdorf, M. and Boots, B. (1995) The exact distribution of Moran's I, Environment and Planning A, 27 (6 ), 985-999.

Wackernagel, H. (2003) Multivariate Geostatistics: An introduction with applications, $3^{\text {rd }}$ Ed. Berlin: Springer-Verlag.

Worzala, E., Lenk, M. and Silva, A. (1995) An exploration of neural Networks and its application to real estate valuation, Journal of Real Estate Research, 10 (2), 185-202. 


\section{Tables}

Table 1: Premises. Factors and levels

\begin{tabular}{llll}
\hline \multirow{4}{*}{ Premises } & Condition & Surface & Basement \\
\cline { 2 - 4 } & Ready for business & Less than $50 \mathrm{~m}^{2}$ & Yes \\
& $\begin{array}{l}\text { Some renovation needed } \\
\text { Complete renovation needed }\end{array}$ & From 50 to $100 \mathrm{~m}^{2}$ & Not \\
& From 100 to $200 \mathrm{~m}^{2}$ & \\
& Unfinished & More than $200 \mathrm{~m}^{2}$ & \\
\hline
\end{tabular}

Table 2: Houses. Factors and levels

\begin{tabular}{llll}
\hline \multirow{4}{*}{ Houses } & Condition & Surface & Parking \\
\cline { 2 - 3 } & New or completely renovated & Less than $65 \mathrm{~m}^{2}$ & Yes \\
& $\begin{array}{l}\text { In a good condition } \\
\text { Little renovation needed } \\
\text { Complete renovation needed }\end{array}$ & From 65 to $120 \mathrm{~m}^{2}$ & Not \\
& More than $120 \mathrm{~m}^{2}$ & \\
\hline
\end{tabular}

Table 3: Moran's I statistics results for premises and housing prices at 2007 and 2009.

\begin{tabular}{lccccc}
\hline & & $\begin{array}{c}\text { Sample value } \\
\text { I-statistic }\end{array}$ & $\begin{array}{c}\text { Mean } \\
\text { Value E(I) }\end{array}$ & $\begin{array}{c}\text { Variance } \\
\mathbf{V}(\mathbf{I})^{\mathbf{1}}\end{array}$ & $\begin{array}{c}\text { Standardized } \\
\text { values }\end{array}$ \\
\hline \multirow{2}{*}{ Q3-2007 } & Premises & 0.022 & -0.0413 & 0.00015 & 5.2348 \\
& Houses & 0.125 & -0.0083 & 0.00032 & 7.4429 \\
\hline \multirow{2}{*}{ Q3-2009 } & Premises & 0.034 & -0.0049 & 0.00012 & 3.5782 \\
& Houses & 0.098 & -0.0094 & 0.00027 & 6.5361 \\
\hline${ }^{1}$ Under the null hypothesis of randomness. & & &
\end{tabular}

Table 4. Linear Model of Coregionalization Results for Q3 2007 and Q3 2009.

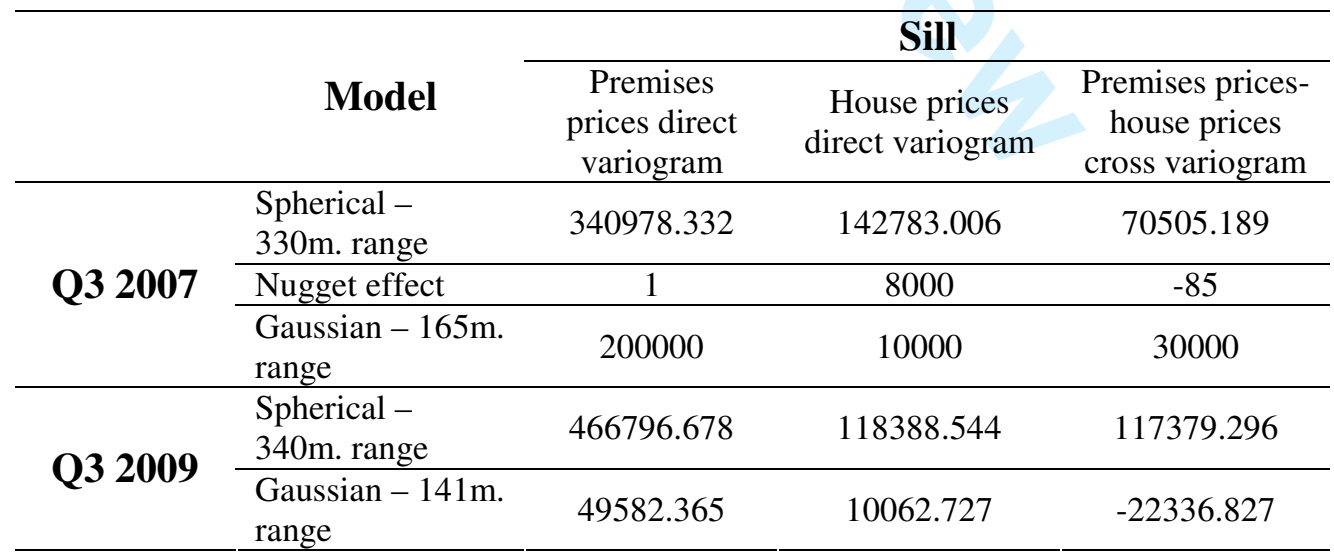


Table 5. Basic statistics for ordinary cokriged estimates of the price of "equivalent" premises. Results from Q3 2007 and Q3 2009.

\begin{tabular}{clcccccccc}
\hline & Min & $\mathbf{Q}_{\mathbf{2 5}}$ & $\mathbf{Q}_{\mathbf{5 0}}$ & $\mathbf{Q}_{\mathbf{7 5}}$ & Max & Mean & St. dev. & $\begin{array}{c}\text { Variation } \\
\text { coeff. }\end{array}$ \\
\hline $\mathbf{2 0 0 7}$ & $\begin{array}{l}\text { Cokriged } \\
\text { price }\end{array}$ & 643.03 & 1399.28 & 1968.76 & 2316.51 & 4475.47 & 1975.77 & 738.18 & 0.374 \\
\hline $\begin{array}{l}\text { Standard } \\
\text { deviation }\end{array}$ & 0 & 229.74 & 339.98 & 544.91 & 852.95 & 395.83 & 197.74 & 0.499 \\
\hline $\mathbf{2 0 0 9}$ & $\begin{array}{l}\text { Cokriged } \\
\text { price }\end{array}$ & 721.00 & 1466.79 & 1802.64 & 2089.11 & 4284.53 & 1828.56 & 545.78 & 0.298 \\
\hline $\begin{array}{l}\text { Standard } \\
\text { deviation }\end{array}$ & 0 & 289.62 & 422.96 & 612.60 & 744.68 & 445.95 & 175.90 & 0.394 \\
\hline
\end{tabular}

Table 6. Cross-validation results

\begin{tabular}{llrrrr}
\hline & \multirow{2}{*}{ Interpolation Method } & \multicolumn{2}{c}{ Error } & \multicolumn{2}{c}{$\begin{array}{c}\text { Standardized } \\
\text { error }\end{array}$} \\
\cline { 2 - 5 } & & Mean & Variance & Mean & Variance \\
\hline \multirow{2}{*}{ Q3 2007 } & $\begin{array}{l}\text { Inverse Distance } \\
\text { Weigthing }\end{array}$ & -18.240 & 97779.020 & - & - \\
\cline { 2 - 5 } & Kriging & -1.672 & 91186.233 & -0.015 & 1.097 \\
\cline { 2 - 6 } & Cokriging & 1.501 & 80621.447 & 0.0045 & 0.922 \\
\hline \multirow{2}{*}{ Q3 20099 } & Inverse Distance & -20.347 & 99320.372 & - & - \\
\cline { 2 - 6 } & Weigthing & -1.850 & 95438.844 & -0.054 & 1.129 \\
\cline { 2 - 6 } & Kriging & 1.608 & 92007.087 & 0.022 & 1.019 \\
\hline
\end{tabular}




\section{Figures}

FIGURE 1: Historical part of Toledo city map.

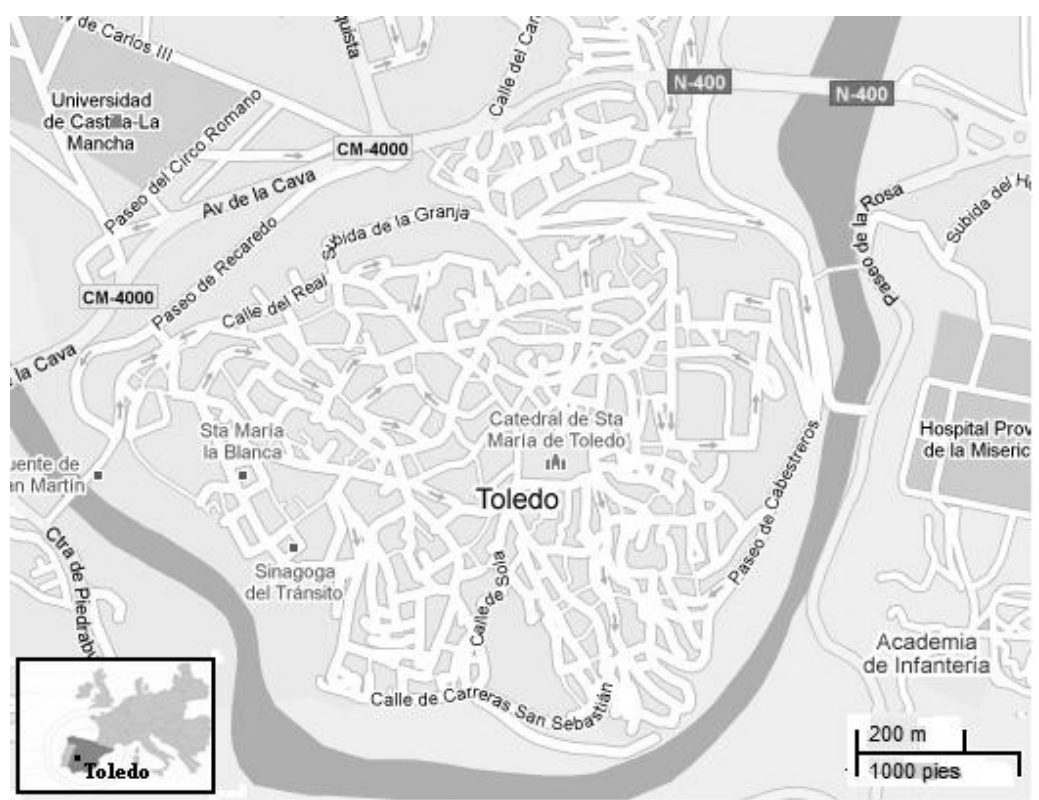

FIGURE 2: Experimental and fitted (a) premises prices direct variogram Q3-2007, (b) house prices direct variogram Q3-2007, (c) premises priceshouse prices cross-variogram Q3-2007, (d) premises prices direct variogram Q3-2009, (e) house prices direct variogram Q3-2009, (f) premises priceshouse prices cross-variogram Q3-2009.

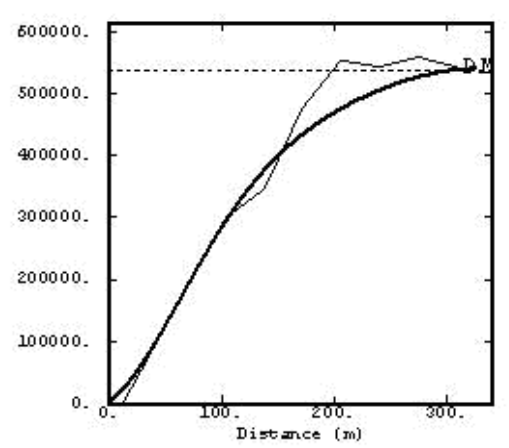

(a)

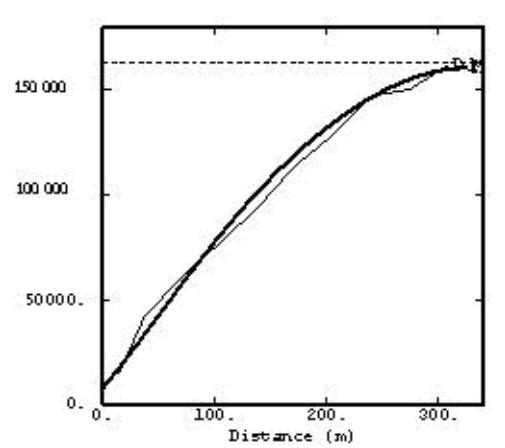

(b) 


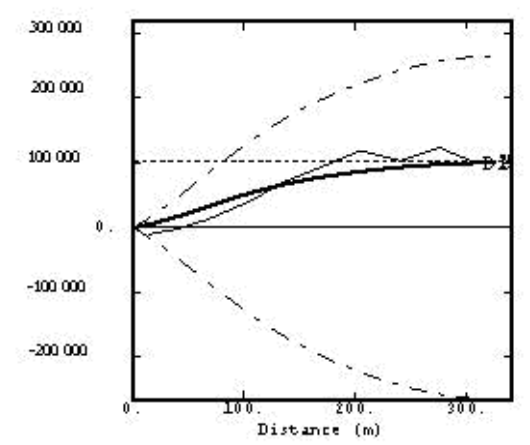

(c)

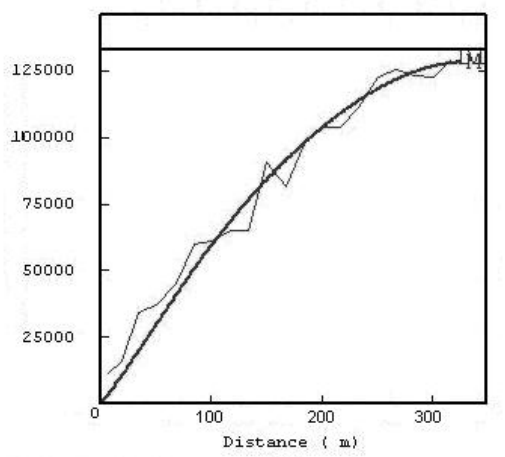

(e)

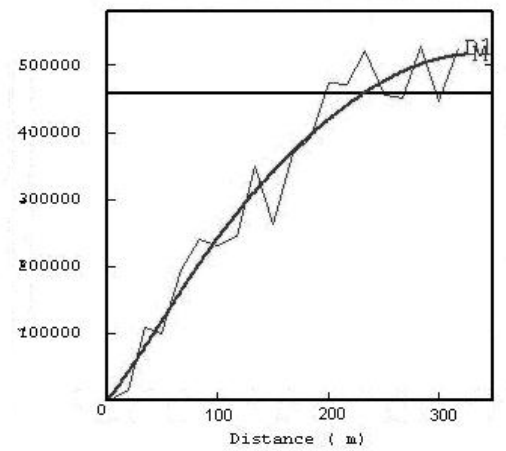

(d)

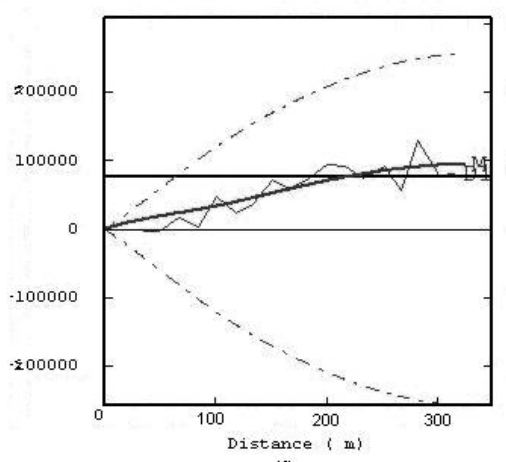

(f)

FIGURE 3: Cokriging valuation of commercial property prices $\left(€ / \mathrm{m}^{2}\right)$. Maps corresponding to Q3 2007 and Q3 2009.
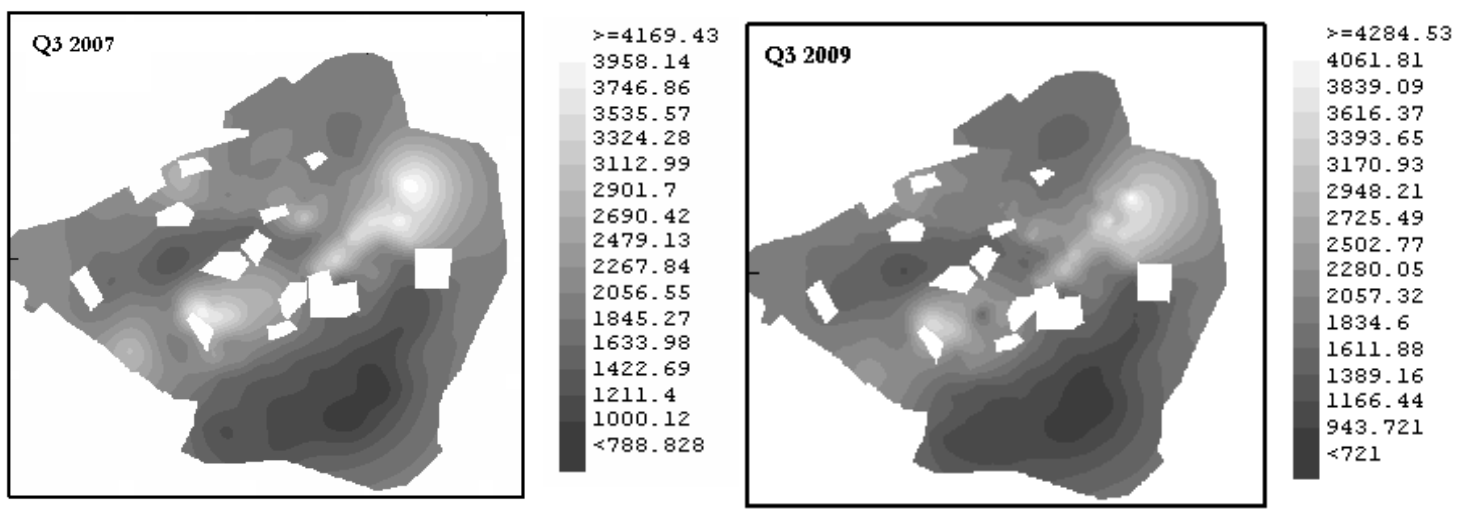

Editorial Office, Dept of Economics, Warwick University, Coventry CV4 7AL, U 
FIGURE 4: Standard deviation corresponding to the cokriged valuation of the commercial property prices. Maps corresponding to Q3 2007 and Q3 2009.
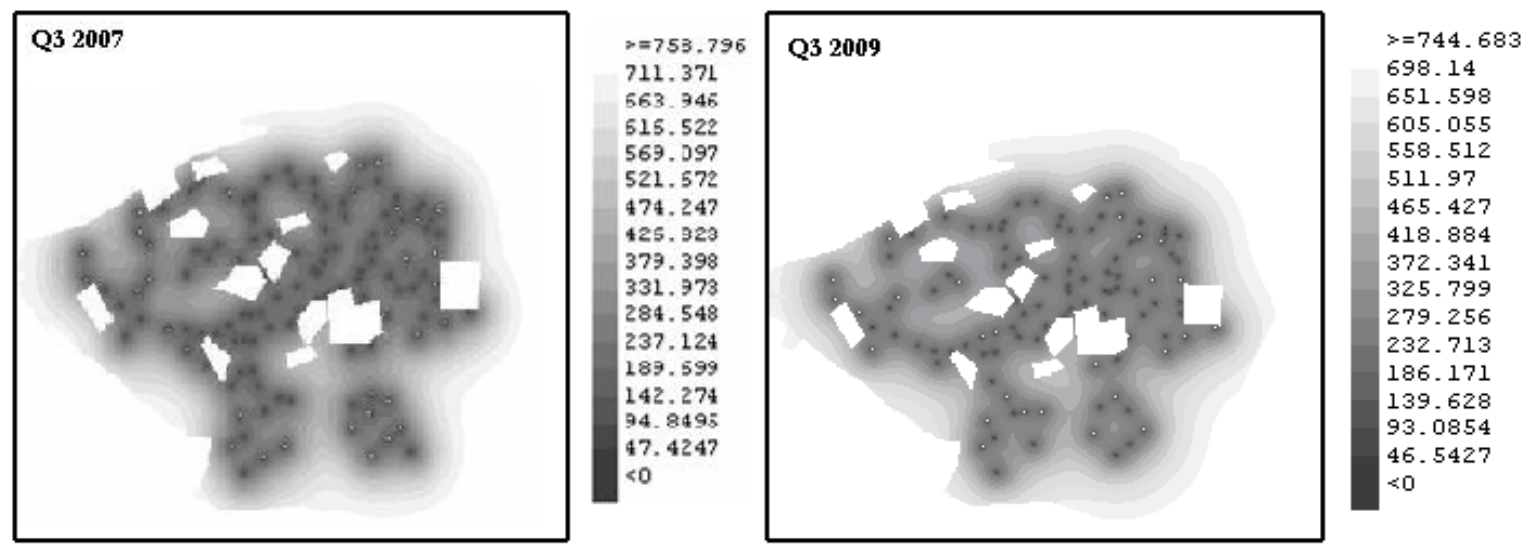


\section{Figures}

FIGURE 1: Historical part of Toledo city map.

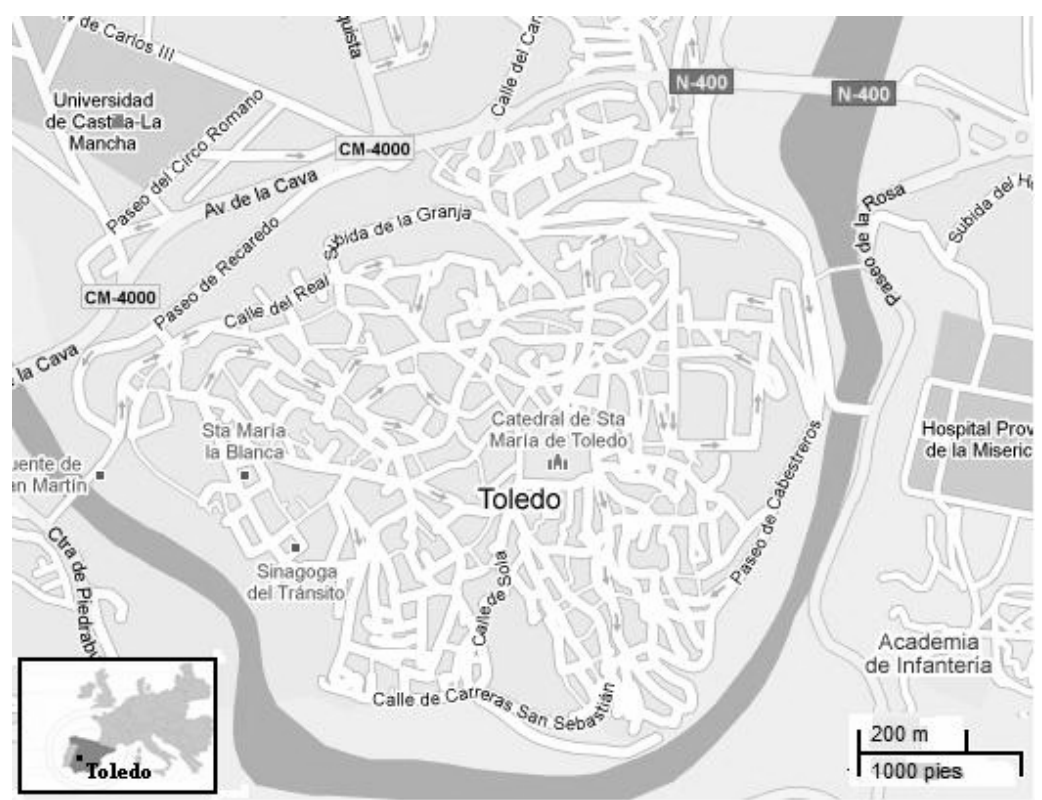

FIGURE 2: Experimental and fitted (a) premises prices direct variogram Q3-2007, (b) house prices direct variogram Q3-2007, (c) premises priceshouse prices cross-variogram Q3-2007, (d) premises prices direct variogram Q3-2009, (e) house prices direct variogram Q3-2009, (f) premises priceshouse prices cross-variogram Q3-2009.

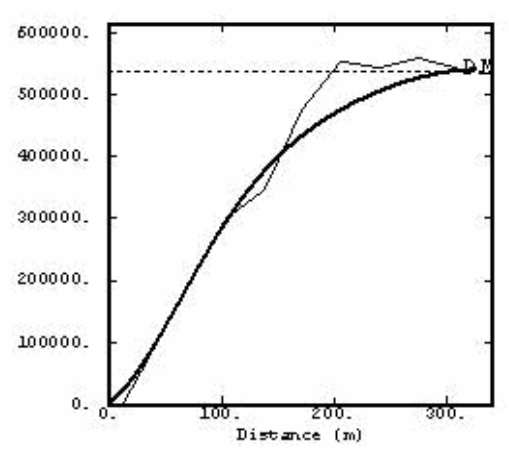

(a)

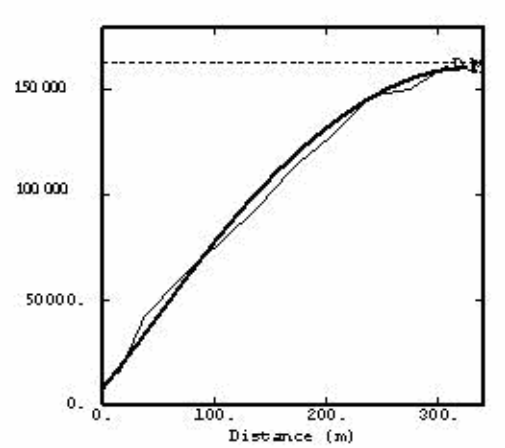

(b) 


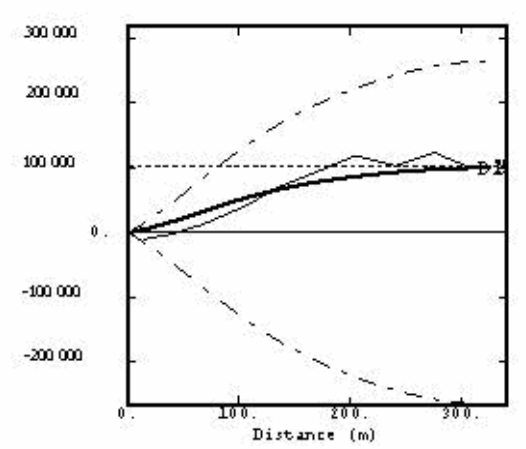

(c)

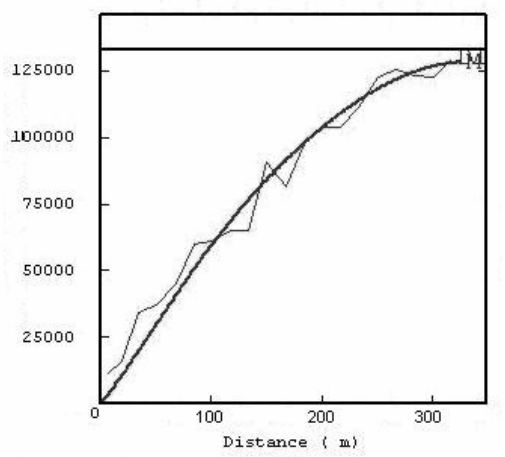

(e)

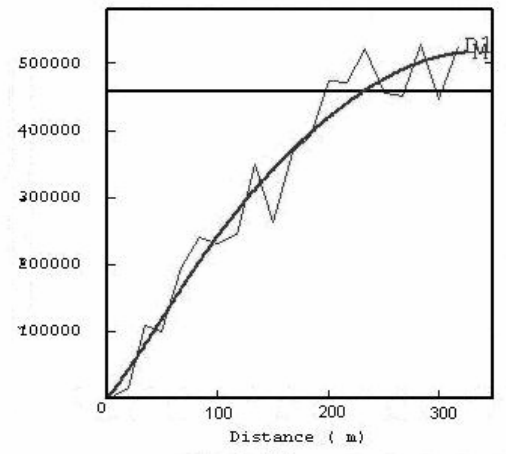

(d)

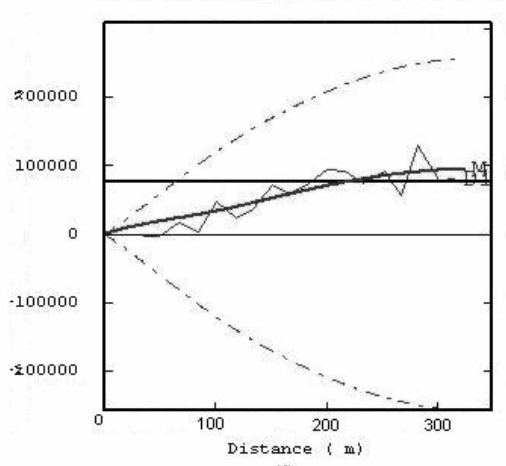

(f)

FIGURE 3: Cokriging valuation of commercial property prices $\left(€ / \mathrm{m}^{2}\right)$. Maps corresponding to Q3 2007 and Q3 2009.
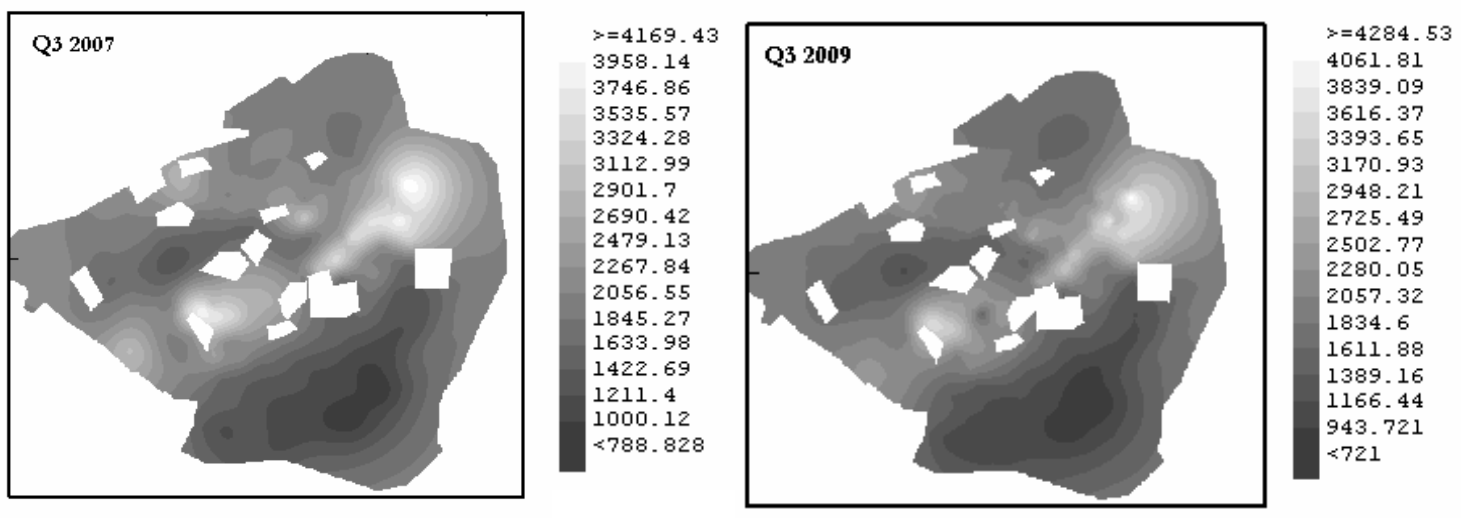

Editorial Office, Dept of Economics, Warwick University, Coventry CV4 7AL, Ứ 
FIGURE 4: Standard deviation corresponding to the cokriged valuation of the commercial property prices. Maps corresponding to Q3 2007 and Q3 2009.
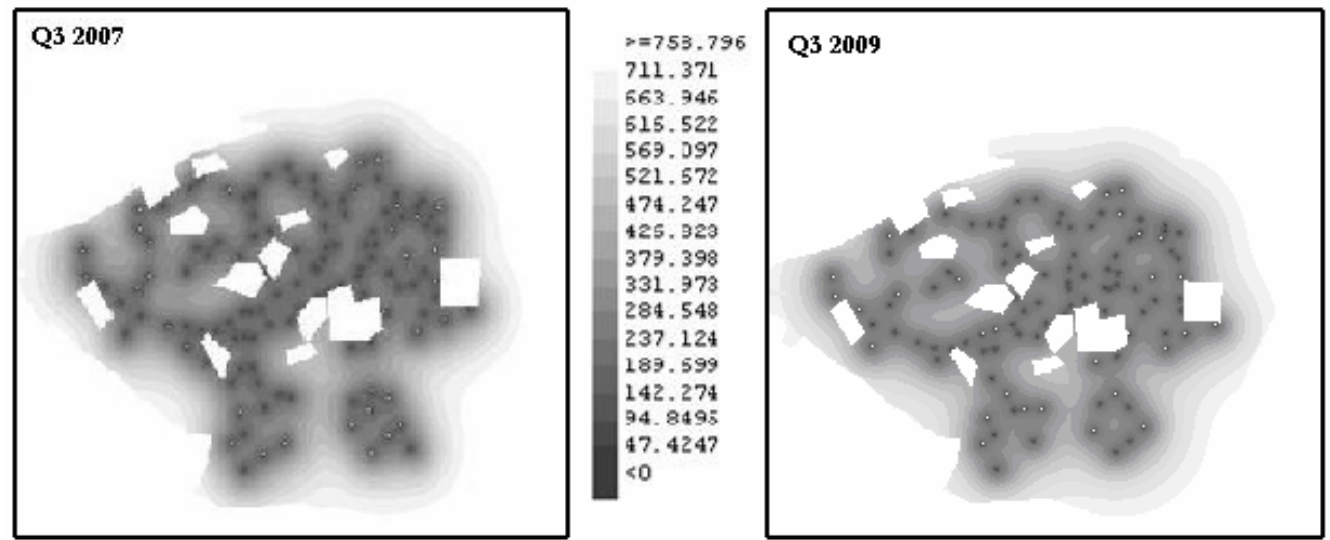

$>=744.683$ 698.14 651.598 605.055

558.512

511.97

465.427

418.884

372.341

325.799

279.256

232.713

186.171

139.628

139.628

46.5427 
Tables

Table 1: Premises. Factors and levels

\begin{tabular}{llll}
\hline \multirow{4}{*}{ Premises } & Condition & Surface & Basement \\
\cline { 2 - 4 } & Ready for business & Less than $50 \mathrm{~m}^{2}$ & Yes \\
& $\begin{array}{l}\text { Some renovation needed } \\
\text { Complete renovation needed } \\
\text { Unfinished }\end{array}$ & From 50 to $100 \mathrm{~m}^{2}$ & Not \\
& From 100 to $200 \mathrm{~m}^{2}$ & \\
More than $200 \mathrm{~m}^{2}$ & \\
\hline
\end{tabular}

Table 2: Houses. Factors and levels

\begin{tabular}{llll}
\hline \multirow{4}{*}{ Houses } & Condition & Surface & Parking \\
\cline { 2 - 3 } & New or completely renovated & Less than $65 \mathrm{~m}^{2}$ & Yes \\
& In a good condition & Little renovation needed \\
& Complete renovation needed 65 to $120 \mathrm{~m}^{2}$ & Not \\
& More than $120 \mathrm{~m}^{2}$ & \\
\hline
\end{tabular}

Table 3: Moran's I statistics results for premises and housing prices at 2007 and 2009.

\begin{tabular}{lccccc}
\hline & Sample value & $\begin{array}{c}\text { Mean } \\
\text { I-statistic }\end{array}$ & $\begin{array}{c}\text { Variance } \\
\text { Value }(\mathbf{I})^{\mathbf{1}}\end{array}$ & $\begin{array}{c}\text { Standardized } \\
\text { Values }\end{array}$ \\
\hline \multirow{2}{*}{ Q3-2007 } & Premises & 0.022 & -0.0413 & 0.00015 & 5.2348 \\
& Houses & 0.125 & -0.0083 & 0.00032 & 7.4429 \\
\hline \multirow{2}{*}{ Q3-2009 } & Premises & 0.034 & -0.0049 & 0.00012 & 3.5782 \\
& Houses & 0.098 & -0.0094 & 0.00027 & 6.5361 \\
\hline
\end{tabular}

${ }^{1}$ Under the null hypothesis of randomness.

Table 4. Linear Model of Coregionalization Results for Q3 2007 and Q3 2009.

\begin{tabular}{|c|c|c|c|c|}
\hline & \multirow[b]{2}{*}{ Model } & \multicolumn{3}{|c|}{ Sill } \\
\hline & & $\begin{array}{c}\text { Premises } \\
\text { prices direct } \\
\text { variogram } \\
\end{array}$ & $\begin{array}{c}\text { House prices } \\
\text { direct variogram }\end{array}$ & $\begin{array}{c}\text { Premises prices- } \\
\text { house prices } \\
\text { cross variogram }\end{array}$ \\
\hline \multirow{3}{*}{ Q3 2007} & $\begin{array}{l}\text { Spherical- } \\
\text { 330m. range }\end{array}$ & 340978.332 & 142783.006 & 70505.189 \\
\hline & Nugget effect & 1 & 8000 & -85 \\
\hline & $\begin{array}{l}\text { Gaussian }-165 m \text {. } \\
\text { range }\end{array}$ & 200000 & 10000 & 30000 \\
\hline \multirow{2}{*}{ Q3 2009} & $\begin{array}{l}\text { Spherical - } \\
\text { 340m. range }\end{array}$ & 466796.678 & 118388.544 & 117379.296 \\
\hline & $\begin{array}{l}\text { Gaussian }-141 \mathrm{~m} . \\
\text { range }\end{array}$ & 49582.365 & 10062.727 & -22336.827 \\
\hline
\end{tabular}


Table 5. Basic statistics for ordinary cokriged estimates of the price of "equivalent" premises. Results from Q3 2007 and Q3 2009.

\begin{tabular}{cccccccccc}
\hline & Min & $\mathbf{Q}_{\mathbf{2 5}}$ & $\mathbf{Q}_{\mathbf{5 0}}$ & $\mathbf{Q}_{\mathbf{7 5}}$ & Max & Mean & St. dev. & $\begin{array}{c}\text { Variation } \\
\text { coeff. }\end{array}$ \\
\hline $\mathbf{2 0 0 7}$ & $\begin{array}{l}\text { Cokriged } \\
\text { price }\end{array}$ & 643.03 & 1399.28 & 1968.76 & 2316.51 & 4475.47 & 1975.77 & 738.18 & 0.374 \\
\hline $\begin{array}{l}\text { Standard } \\
\text { deviation }\end{array}$ & 0 & 229.74 & 339.98 & 544.91 & 852.95 & 395.83 & 197.74 & 0.499 \\
\hline $\mathbf{2 0 0 9}$ & $\begin{array}{l}\text { Cokriged } \\
\text { price }\end{array}$ & 721.00 & 1466.79 & 1802.64 & 2089.11 & 4284.53 & 1828.56 & 545.78 & 0.298 \\
\hline $\begin{array}{l}\text { Standard } \\
\text { deviation }\end{array}$ & 0 & 289.62 & 422.96 & 612.60 & 744.68 & 445.95 & 175.90 & 0.394 \\
\hline Prices in $€ / \mathrm{m}^{2}$
\end{tabular}

${ }^{1}$ Prices in $€ / \mathrm{m}^{2}$

Table 6. Cross-validation results

\begin{tabular}{|c|c|c|c|c|c|}
\hline & \multirow[t]{2}{*}{ Interpolation Method } & \multicolumn{2}{|c|}{ Error } & \multicolumn{2}{|c|}{$\begin{array}{c}\text { Standardized } \\
\text { error }\end{array}$} \\
\hline & & Mean & Variance & Mean & Variance \\
\hline \multirow{3}{*}{ Q3 2007} & $\begin{array}{l}\text { Inverse Distance } \\
\text { Weigthing }\end{array}$ & -18.240 & 97779.020 & - & - \\
\hline & Kriging & -1.672 & 91186.233 & -0.015 & 1.097 \\
\hline & Cokriging & 1.501 & 80621.447 & 0.0045 & 0.922 \\
\hline \multirow{3}{*}{ Q3 2009} & $\begin{array}{l}\text { Inverse Distance } \\
\text { Weigthing }\end{array}$ & -20.347 & 99320.372 & - & - \\
\hline & Kriging & -1.850 & 95438.844 & -0.054 & 1.129 \\
\hline & Cokriging & 1.608 & 92007.087 & 0.022 & 1.019 \\
\hline
\end{tabular}

